\title{
JARGON BAHASA WARIA SUATU KAJIAN PRAGMATIK
}

\author{
Inramini $^{1}$ Sri Jumiati ${ }^{2}$ \\ inramini.umm@gmail.com \\ Pendidikan Bahasa dan Sastra Indonesia, Universitas Muhammadiyah Makassar \\ jumiati@gmail.co.id \\ Pendidikan Bahasa dan Sastra Indonesia, Universitas Muhammadiyah Makassar
}

\begin{abstract}
This study aimed to analyze the Transgender A Jargon Language Pragmatics Study. The method used in this research was a qualitative descriptive method to describe and convey the data objectively. Describing terms Transgender A Jargon Language Pragmatics studies as research objects. Data collection techniques used were two fold: (1) the technique was an interview.Wthe interview conducted structured interviews. The questions were prepared in advance, so as to facilitate comparisons between the data with the other data smoothly and precisely. In addition, it is possible held in unstructured interviews. (2). The data in this study a language jargon description transvestites in a pragmatic study. Results of this study were found some of the jargon in the form of vocabulary and sentence transvestites a pragmatic study. From these results it can be seen that the interaction is more dominant antarwaria use transgender vocabulary when talking.

Keywords: Sex, Jargon and Pragmatics.

Abstrak

Penelitian ini bertujuan untuk menganalisis Jargon Bahasa Waria Suatu Kajian Pragmatik. Metode yang digunakan dalam penelitian ini adalah metode deskriptif kualitatif yaitu memaparkan dan menyampaikan data secara objektif. Mendeskripsikan istilah-istilah Jargon Bahasa Waria Suatu Kajian Pragmatik sebagai objek penelitian. Teknik pengumpulan data yang digunakan ada dua yaitu: (1) Teknik wawanacara.Wawancara yang dilakukan adalah wawancara terstruktur. Pertanyaanpertanyaan yang telah dipersiapkan lebih dahulu, sehingga memudahkan perbandingan antara satu data dengan data lain secara lancar dan tepat. Selain itu, tidak menutup kemungkinan diadakan wawancara secara tidak berstruktur. (2). Data dalam penelitian ini berupa pendeskripsian jargon bahasa waria dalam suatu kajian pragmatik. Hasil penelitian ini adalah ditemukan beberapa jargon dalam bentuk kosakata dan kalimat bahasa waria suatu kajian pragmatik. Dari hasil penelitian tersebut dapat diketahui bahwa dalam interaksi antarwaria tersebut lebih dominan menggunakan kosakata bahasa waria ketika bercakap.
\end{abstract}

Kata Kunci: Waria, Jargon dan Pragmatik. 


\section{Pendahuluan}

Eksistensi bahasa dalam hidup dan kehidupan di dunia memegang peranan penting, sebab bahasa dan kehidupan sosial adalah hal yang tidak mungkin dipisahkan dalam kehidupan masyarakat, serta interaksi sosial yang tidak akan pernah dapat tercapai tanpa adanya bahasa sebagai alat komunikasi. Bahasa merupakan salah satu wujud kegiatan, dalam kehidupan ini. Jika tidak disertai dengan bahasa yang merupakan sarana komunikasi antarindividu, kelompok, dan antarbangsa maka kehidupan akan statis dan tidak ada interaksi sosial dalam masyarakat. Bahasa menurut Samsuri (1978:16) adalah segala sesuatu yang merupakan isi pikiran, perasaan dan menyatakan wejangan, serta harapan terhadap Allah Swt. Segala ucapan yang manusia lakukan, baik sendiri maupun berkumpul dengan teman pasti menggunakan bahasa. Hal ini terlihat pada kegiatan sehari-hari dan pada kegiatan khusus misalnya pada suatu tempat keramaian, jelas di tengah hiruk pikuknya keramaian tersebut tak henti-hentinya menggunakan bahasa. Demikian juga halnya yang terjadi pada seseorang yang lagi menyendiri, meskipun tidak mempunyai teman untuk berdialog atau berbicara, akan tetapi apabila orang tersebut sadar atau tidak sadar pasti menggunakan bahasa sebagai alat untuk merangsang hasil pikiran dan khayalan. Sudah dimaklumi bahwa fungsi umum yang paling utama bahasa adalah sebagai alat komunikasi yang paling sempurna. Hampir semua aktivitas bahasa sangat dibutuhkan dalam berbagai situasi komunikasi. Oleh sebab itu, bahasa demikian pentingnya pada masalah yang berhubungan dengan bahasa itu sendiri. Perhatian yang dicurahkan pada masalah bahasa tidak saja di kalangan lingkungan, akan tetapi di kalangan ahli dalam bidang lain seperti psikologi, antropologi, dan sosiologi. Bahasa sebagai alat komunikasi juga berkaitan dengan asas sosial dari masyarakat itu sendiri, semua unsur dimasukkan untuk mendapatkan tanggapan, baik berupa tutur, maupun yang berhak berbahasa atau tindakan. Uraian di atas dapat disimpulkan bahwa bahasa merupakan salah satu wujud kegiatan dalam kehidupan sosial.

Penulis bermaksud mengadakan penelitian tentang bahasa yang kini umum dipakai oleh kelompok waria. Para ahli bahasa menganggapnya sebagai salah satu variasi bahasa, yang dewasa ini dikenal dengan istilah jargon. Jargon umumnya berkembang di dalam suatu bidang atau kelompok tertentu. Kita sering mendengar istilah jargon, terutama pada media massa dengan menggunakan kata-kata asing dalam mengungkapkan sesuatu. A. Chaer (2010:68) menjelaskan bahwa jargon adalah variasi sosial yang digunakan secara terbatas oleh kelompok-kelompok sosial tertentu. Ungkapan yang digunakan seringkali tidak dapat dipahami oleh masyarakat umum atau masyarakat di luar kelompoknya. Namun, ungkapan-ungkapan tersebut tidak bersifat rahasia.

\section{Berdasarkan Kamus Besar}

Bahasa Indonesia (KBBI), jargon adalah kosakata khusus yang digunakan di bidang kehidupan (lingkungan) tertentu. Nuryadi (dalam Ribins 1992:62) mendefinisikan jargon adalah laras bahasa yang sengaja dipakai oleh kalangan tertentu tetapi tidak dipahami oleh kalangan di luar kalangan tersebut. Jargon biasanya berkenaan dengan kosa kata khusus yang digunakan dalam bidang kehidupan tertentu. Kadang istilah jargon membuat kita bingung, karena sebenarnya jargon merupakan jenis kata atau kalimat berbicara yang digunakan dalam kelompok orang-orang 
tertentu dalam bidang yang sama, yang mungkin tidak diketahui oleh orang lain. Jargon ini pulalah yang sering digunakan oleh waria dalam berkomunikasi dengan kelompoknya.

Waria adalah laki-laki yang lebih suka berperan sebagai perempuan dalam kehidupannya sehari-hari. Keberadaan waria telah tercatat lama dalam sejarah dan memiliki posisi yang berbeda-beda dalam setiap masyarakat. Walaupun dapat terkait dengan kondisi fisik seseorang, gejala waria merupakan bagian dari aspek sosial transgenderisme. Seorang laki-laki memilih menjadi waria dapat terkait dengan keadaan biologisnya (hermafroditisme), orientasi seksual (homoseksualitas), maupun akibat kondisi lingkungan pergaulan. Sebutan bencong juga dikenakan terhadap waria yang bersifat negatif.

Menurut penelitian, penyebab utama seseorang menjadi waria adalah faktor lingkungan. Sejak lahir, waria memang penuh dengan konflik. Pada mulanya mereka dihadapkan pada dua pilihan, menjadi laki-laki atau perempuan. Kedua pilihan ini tentu membawa konsekuensi masing-masing. Konflik lain muncul ketika mereka berada di tengah-tengah masyarakat di sekitarnya yang penuh dengan normanorma dan aturannya sendiri. Kehadiran mereka di tengah masyarakat dianggap sebagai sampah masyarakat yang tidak memiliki hak dan kewajiban yang sama sebagaimana layaknya manusia lainnya. Faktor ekonomi juga sebagai pemicu, jadi para lelaki banyak yang berperan sebagai waria, hal ini terjadi karena sulitnya mencari lapangan pekerjaan, demi mendapatkan penghidupan yang layak mereka berani menyatakan diri sebagai waria dengan penampilan mereka menggunakan rok yang mencerminkan seorang wanita yang seutuhnya.

Waria merupakan sekelompok bagian dari masyarakat yang mempunyai komunitas tersendiri. Sesama waria dalam menggunakan bahasa tertentu dilihat dari situasi tertentu yang disebut ragam bahasa. Perkembangan bahasa pada kalangan waria dilengkapi dan diperkaya oleh lingkungan masyarakat tempat mereka tinggal. Hal ini berarti sebuah proses pembentukan karakteristik yang dihasilkan dari pergaulan dengan masyarakat di sekitar akan menjadi ciri khusus dalam sebuah perilaku bahasa. Pembicaraan tentang ragam bahasa biasanya dikaitkan dengan masalah dialek. Kalau dialek berkenaan dengan bahasa yang digunakan oleh siapa, dimana, dan kapan, maka ragam berkenaan dengan masalah bahasa itu digunakan untuk kegiatan apa.

Istilah pragmatik pertama- tama digunakan oleh filosof kenamaan Charles Morris (1938). Filosof ini memang mempunyai perhatian besar terhadap ilmu yang mempelajari sistem tanda (semiotik). Dalam semotik ini, dia membedakan tiga konsep dasar yaitu sintaksis, semantik, dan pragmatik. Sintaksis mempelajari hubungan antara tanda dengan objek. Pragmatik mengkaji hubungan antara tanda-tanda, yang dimaksud disini adalah tanda-tanda bahasa bukan yang lain.

Berbeda dengan Charles Morris, Carnap (1938) seorang filosof dan ahli logika menjelaskan bahwa pragmatik mempelajari konsep-konsep abstrak tertentu yang menunjukkan pada agents. Dengan perkataan lain, pragmatik mempelajari hubungan konsep yang merupakan tanda dengan pemakai tanda tersebut. Levinson (1983) dalam 
bukunya yang berjudul Pragmatiks, memberikan beberapa batasan tentang pragmatik. Beberapa batasan yang dikemukakan Levinson antara lain mengatakan bahwa pragmatik adalah kajian yang berhubungan antara bahasa dan konteks yang mendasari penjelasan pengertian bahasa. Dalam batasan ini berarti untuk memahami pemakaian bahasa kita dituntut memahami pula konteks yang mewadahi pemakaian bahasa tertentu. Batasan lain yang yang dikemukakan Levinson mengatakan bahwa pragmatik adalah kajian tentang kemampuan pemakai bahasa untuk mengaitkan kalimat-kalimat dengan konteks yang sesuai bagi kalimatkalimat itu.

Pendapat yang agak berbeda tentang pragmatik oleh Morris (1938), pragmatik sebagai suatu kajian ilmu muncul dari pandangan Morris tentang semiotik, yaitu ilmu yang mempelajari sistem tanda atau lambang. Morris membagi semiotik ke dalam tiga cabang ilmu, yaitu sintaksis, semantik, dan pragmatik. Semantik mempelajari hubungan antara lambang dengan objeknya, dan pragmatik mempelajari hubungan antara lambang dengan penafsirannya.

Saidi (2010:4) menyimpulkan dari defenisi para ahli bahwa pragmatik adalah kajian tentang penggunaan atau menelaah makna bahasa yang berkaitan erat dengan unsur konteks peserta tutur. Berdasarkan latar belakang yang telah dikemukakan di atas, penulis tertarik untuk meneliti jargon bahasa waria dalam suatu kajian pragmatik

\section{Metode Penelitian}

\section{a. Desain Penelitian}

Penelitian ini bersifat deskriptif, oleh karena itu penelitian mendeskripsikan istilah-istilah jargon bahasa waria dalam suatu kajian pragmatik. Untuk menambah bahan penelitian, peneliti juga membaca secara saksama literatur lain yang relevan dengan objek penelitian.

\section{b. Batasan Istilah}

Batasan istilah adalah batasan yang didasarkan atas sifat-sifat yang dapat diamati. Peneliti bebas merumuskan, menentukan definisi istilah sesuai dengan tujuan penelitian dan tatanan dari variabel yang ditelitinya. Agar tidak terjadi kesimpangsiuran pemahaman dalam penulisan ini, sehingga dijelaskan terlebih dahulu istilah yang dimaksud yaitu:

1. Jargon adalah kosakata khusus yang digunakan dalam bidang kehidupan (lingkungan) tertentu.

2. Waria adalah pria yang bersifat dan bertingkahlaku seperti wanita dan mempunyai perasaan sebagai wanita.

3. Kosa kata bahasa waria merupakan perubahan bentuk dari kosa kata yang umum digunakan oleh masyarakat.

4. Struktur kalimat bahasa waria merupakan wujud dari rentetan kata yang disusun tidak sesuai dengan kaidah yang berlaku.

5. Gaya bahasa waria adalah cara mengungkapkan perasaan atau pikiran dengan bahasa sedemikian rupa.

\section{c. Data dan Sumber Data}

\section{Sumber Data}

Sumber data yang diperoleh yaitu dari informasi, percakapan yang berupa dialog-dialog yang dilakukan di lingkungan waria. Adapun kriteria penetapan waria yaitu waria yang bisa terbuka dan aktif bersosialisasi dengan masyarakat umum.

2. Data 
Data dalam penelitian ini berupa pendeskripsian jargon bahasa waria dalam suatu kajian pragmatik.

\section{d. Teknik Pengumpulan Data}

Teknik pengumpulan data dalam penelitian ini dilakukan dengan berbagai cara yaitu:

1. Teknik Wawancara

Wawancara yang dilakukan adalah wawancara terstruktur. Pertanyaan-pertanyaan yang telah dipersiapkan lebih dahulu, sehingga memudahkan perbandingan antara satu data dengan data lain secara lancar dan tepat. Selain itu, tidak menutup kemungkinan diadakan wawancara secara tidak berstruktur.

\section{Dokumentasi}

Pencatatan atau pengarsipan data dilakukan dengan baik pada buku catatan khusus maupun kartu-kartu data yang telah dipersiapkan.

\section{e. Teknik Analisis Data}

Teknik analisis data merupakan upaya untuk mencari dan menata secara sistematis catatan hasil pengamatan sehingga dapat menghasilkan pemahaman yang tepat terhadap data tersebut. Langkah-langkah dalam teknik analisis data dilakukan dengan cara sebagai berikut:

1. Mengidentifikasi data dalam bentuk dokumentasi.

2. Mengklasifikasikan masing-masing data yang relevan sesuai dengan masalah.

\section{Hasil Penelitian dan Pembahasan a. Hasil Penelitian}

Pada bagian ini dikemukakan hasil penelitian berupa data tentang penggunaan jargon bahasa waria dalam kajian pragmatik dalam interaksi sesama waria.

Data yang diperoleh dari lapangan berbentuk catatan dan rekaman percakapan waria yang menjadi bahan mentah observasi. Sebelum peneliti merekam percakapan waria, peneliti melakukan perkenalan. Dari hasil perkenalan tersebut, waria yang menjadi objek peneliti berkomunikasi seperti biasanya dan peneliti menemukan penggunaan bahasa jargon dalam percakapan waria tersebut.

Selanjutnya, dilakukan proses rekaman percakapan waria, percakapan dilakukan dengan cara berdampingan atau berpasangan satu sama lain dan saling melontarkan pembicaraan. Bentuk pembicaraan atau tema yaitu secara bebas, menghasilkan beberapa kalimat percakapan bahasa jargon yang selanjutnya rekaman tersebut diubah dalam bentuk tertulis. Hasil penelitian ditemukan beberapa jargon dalam bentuk kosakata dan kalimat bahasa waria suatu kajian pragmatik. Dari hasil penelitian tersebut dapat diketahui bahwa dalam interaksi antarwaria tersebut lebih dominan menggunakan kosakata bahasa waria ketika bercakap. Data yang ditemukan dalam penelitian ini sebagai berikut.

\section{Penggunaan Kosakata Bahasa Waria}

Berdasarkan temuan penelitian, penggunaan kosakata bahasa waria yang berhasil dicatat oleh peneliti sebanyak 50 kosakata yang dominan digunakan dalam percakapan waria sehari-hari. Jumlah kata tersebut masih sangat minim bila dibandingkan jumlah kata yang digunakan dalam berkomunikasi seperti bahasa Indonesia dan diperkirakan masih terus berkembang sesuai dengan perkembangan komunikasi dunia waria yang akan datang. Keterbatasan jumlah tersebut dapat dipastikan bahwa bahasa jargon belum dapat mewakili sepenuhnya dalam mengungkapkan semua ide, gagasan, dan sebagainya kepada orang lain. Oleh karena itu, penggunaan kosakata dalam bahasa waria hanya 
digunakan melalui proses penyisipan dalam berkomunikasi bahasa Indonesia maupun bahasa daerah sehingga bagi orang yang mendengar tidak langsung dapat menebak atau mengetahui informasi yang disampaikan. Sebab, adanya hal-hal yang spesifik dalam bahasa waria tidak terdapat dalam bahasa Indonesia. Untuk jelasnya dapat dilihat dalam paparan berikut.

1) Penggunaan kosakata bahasa waria bersumber dari penggunaan nama orang (NO). Nama orang yang digunakan adalah nama yang sudah lazim dikenal oleh masyarakat seperti:

1. Diana

2. Hamidah

$$
\text { artinya Dia }
$$

3. Habiba artinya Hamil artinya Habis

4. Vetty Vera artinya Sedang-sedang

5. Maharani artinya Mahal

6. Titi DJ di jalan artinya Hati-hati

2) Penggunaan kosakata bahasa waria bersumber dari nama binatang seperti:

1. Belalang artinya Belanja

2. Cumi artinya Cium

3) Penggunaan kalimat tanya pada bahasa waria:

1. Kamu dari mana? artinya mandose?

2. Mau kemana? mandala?

3. Sudah makan?

4. Orang mana? mandai?

5. Dimana rumahmu? artinya langka' dimandose?

6. Siapa namamu? artinya desamu sapose?

4) Penggunaan kosakata yang bersumber dari hal-hal lain:

1. Ora

2. Apose

3. Dimandai

artinya Tidak

artinya Apa

4. Sindang artinya Dimana

5. Onomineka artinya Sini

6. Siapa artinya Bisa

7. Lembayu artinya Sapose

artinya Lumayan
8. Lapangan Bola artinya Lapar

9. Akika, Kulo' artinya Aku

10. Sampeyang artinya Kamu

11. Lekong

12. Wedo

13. Wandu

14. Depong

15. Bala-bala

16. Cap-cus

17. Longka

18. Penjong

19. Orro

20. Ojo

21. Mesong

22. Bias Kasih

23. Kotto

24. Centong

25. Cuco

26. Begindang

27. Belenjong

28. Jali-jali jalan

29. Kencana

30. Metong

31. Sekong

32. Capcay

33. Pecongan

34. Tammi

35. Turo

36. Tabo

di 37. Ono

38. Tuladeng

39. Banyu

40. Desa

41. Kori

42. Dendang artinya Cowok artinya Perempuan artinya Waria artinya Dapat artinya Bayaran artinya Cepat artinya Besar artinya Panjang artinya Tahu artinya Jangan artinya Mau artinya Biasa-biasa artinya Jelek artinya Cantik artinya Ganteng artinya Begitu artinya Belanja artinya Jalan-

artinya Kencing artinya Mati artinya Sakit artinya Cape

artinya Pacaran artinya Minum

artinya Tidur artinya Makan artinya Datang artinya Duduk artinya Mandi artinya Nama artinya Uang artinya Elekton

\section{Penggunaan Kalimat Tanya Bahasa Waria}

Selama proses penelitian berlangsung, peneliti menemukan percakapan antarwaria di salah satu salon di daerah Galesong Kabupaten Takalar. Berikut petikan percakapan waria dan artinya dalam bahasa Indonesia.

$$
\begin{aligned}
\text { Ayu } & \text { Apa Kijamma? } \\
& \text { (Lagi bikin apa?) }
\end{aligned}
$$


Kiki $=$ Ora ja bataring, katte iyya apa kijamma?

(Tidak....., kamu sendiri

lagi bikin apa?)

Ayu = Ora ja, pakabella ja ri embong, sampeang?

(Tidak,....banyak

mungkin orang cukurmu?)

Kiki $=$ Ora kodong,...setiti.

(Tidak, Cuma satu)

Ayu = Jai antu kori'mu?

(Banyak itu uangmu?)

Kiki = Ora na, sumpung kapang kipake belle di embong?

(Tidak, ....ada mungkin orang bondingmu?) nidayong

Ayu $=$ Ora de'e...titi kori ji uang didapat)

(Tidak,...hanya sedikit

Kiki $=\mathrm{Ka}$ nadesai Kak Ila,...sumpu'ko bonselta?

Ila,......banyak?)

(Kata kak

Ayu = Ora...pito-pito ji

(Tidak,.....hanya satu-

satu)

Kiki $=$ Eto'na,.....orang to mau ke dendange?

nanti itu elekton?)

(Jangan bohong,...ada

Ayu = Dimandai dendang?

(Dimana ada elekton?)

Kiki $=$ Di Tonasa

(Di Tonasa)

Pada percakapan tersebut, para waria menggunakan kalimat-kalimat tanya ketika sedang membahas mengenai pelanggan salon dan membahas mengenai elekton. Dalam percakapannya, mereka memakai bahasa daerah dan bahasa waria. Berikut petikan lain percakapan antarwaria di salah satu salon di daerah Bontoramba Kabupaten Gowa.

$$
\text { Lili = cucoknu }
$$

le'...o..kuatiri....., dari manako le'.....? (cantikmu le'...,

khawatir..., kamu dari mana le'?)

Sahira $=$ dari rumah

(dari rumah)

Lili = tawwa....dari langka' nu

le'..?

le'?)

(wah....dari rumahmu

Lili = pake apako kesini le'...? (naik apa kesini le'?)

Sahira $=$ pake motor... (pake motor)

Lili $=$ oooo.....tintingan..., sumpungka' nikatu'na bataring? (ooo.....motor...., berapa pengantinmu?)

Sahira $=$ oo......kuatir... (ooo...khawatir)

Lili = eto'na anjo (banyaknya itu)

Sahira $=$ ora

$$
\text { (tidak) }
$$

Lili = iyo le',....piro..? (iya le' berapa

bayarannya?)

Lili $=$

dimandai

nikes....dimandai...?

(dimana

nikah.....dimana...?)

Sahira = ada di Pammandongan, ada di Parappa....

ada di Parappa)

(ada di Pammandongan,

Lili = tawwa,....sumpu' meki kemanamana cus...., piro anjo sici katu'?

(wah.....berarti kamu sudah bisa pergi kemana-mana..., berapa itu sewanya?)

Sahira $=$ ada 3 jeti,...ada 5 jeti...

(ada 3 juta,...ada 5 juta..

Lili $=$ iiiii....kuatna tappangjoro kammangke, tarrangna...piro minjo neka lanangmu...?

(iii..kuatnya..banyak mungkin itu untuk bayar cowokmu..?)

Sahira $=$ iii...ora de'e..

(tidaklah)

b. Pembahasan 


\section{Pemaknaan Kosakata Bahasa Waria}

Proses pemaknaan dalam bahasa waria tidak sama dengan proses pemaknaan dalam bahasa Indonesia. Proses pemaknaan dalam bahasa waria dilakukan dengan sistem silang. Sistem silang yang dimaksud meliputi antara kata yang dimaknai dengan kata yang memaknai : Kata yang dimaknai sebagai kata yang digunakan untuk mengungkapkan maksud, sedangkan kata yang memaknai adalah kata yang menjadi maksud.

Kosakata bahasa waria di atas, dapat dinyatakan bahwa penggunaan kosakata bahasa waria bersumber dari kosakata bahasa Indonesia sebagai asal kosakata bahasa waria diposisikan secara integratif sehingga membentuk suatu pembaharuan kosakata yang dapat menciptakan maksud tertentu. Maksud yang diciptakan dalam bahasa waria menyimpang dari maksud yang telah lazim diketahui dalam bahasa Indonesia. Dengan demikian, penggunaan kosakata bahasa waria hanya komunikatif pada kalangan penggunaannya saja atau kelompok waria yang telah menggunakannya. Kosakata bahasa waria dalam tinjauan pragmatik dilihat dari konteks tempat, tujuan, dan penutur. Penggunaan kosakata dilihat dari konteks tempat, berbeda antara tempat di kawasan perkotaan dan kawasan pedalaman. Kosakata bahasa waria di kawasan perkotaan cenderung lebih modern dan lebih bervariasi. Kosakata bahasa waria di kawasan pedalaman banyak menyerap kosakata bahasa setempat. Tujuan penggunaan bahasa waria dalam tinjauan pragmatik yaitu untuk merahasiakan maksud pembicaraan dari masyarakat umum karena waria cenderung membahas halhal yang dianggap oleh masyarakat umum kurang sopan. Penutur dalam hal ini yaitu waria memiliki ciri khas dalam pemakaian kosakata. Terdapat banyak variasi tuturan yang digunakan dalam berkomunikasi baik dalam komunikasi langsung maupun ketika sedang membicarakan atau menyinggung orang lain.

\section{Pemaknaan Kalimat Bahasa Waria}

Kalimat "Langka' di mandose" mengungkapkan pertanyaan dimana rumahmu, namun ironisnya pertanyaan tersebut menggunakan bahasa waria yang hanya dipahami oleh kelompok tertentu, sedangkan dalam bahasa Indonesia kalimat "Langka' di mandose" tidak memiliki makna. Misalnya seorang waria bertemu dengan seorang laki-laki biasa dan Ia bertanya dengan menggunakan bahasa waria "Langka' di mandose" yang berarti di mana rumahmu, pasti laki-laki biasa itu tidak dapat memaknai pertanyaan waria tadi, karena pertanyaan waria tadi sudah diserap ke dalam bahasa waria yang bahasanya hanya bisa dipahami oleh sesesama kelompoknya dan tidak dapat dipahami oleh orang di luar kelompok tersebut.

Penggunaan bahasa waria oleh para waria bersumber dari kosakata bahasa Indonesia yang diplesetkan dan bahasa daerah, baik dalam bentuk maupun maknanya. Bentuk dan maknanya menyimpang secara umum dari makna kata yang diketahui dalam bahasa Indonesia maupun bahasa daerah.

Dengan demikian, penggunaan kosakata bahasa waria tidak harus mutlak ada di dalam bahasa Indonesia, walaupun bahasa Indonesia sebagai dasar pembentukan bahasa waria, tetapi kosakata bahasa waria yang digunakan oleh waria, memiliki otonomi tersendiri sebagai suatu bahasa yang dijadikan sebagai suatu sarana komunikasi. 
Ditinjau dari konteks kalimat, kalimat-kalimat bahasa waria umumnya bernuansa kesetaraan sosial kepada para pengguna bahasa waria. Bahasa waria tidak membedakan situasi kapan dan dimana digunakan. Bahasa waria tidak membedakan strata sosial misalnya antara tua atau muda, dewasa atau anakanak dan bidang-bidang lainnya. Bahasa waria hanya dapat digunakan secara khusus dalam situasi pergaulan pada kalangan waria.

Struktur bahasa waria hampir dikatakan tidak ada aturan atau pola tertentu seperti halnya dalam bahasa Indonesia yaitu subjek, predikat, objek, dan keterangan. Bahasa waria lebih mementingkan komunikasi dan makna kerahasiaan kata-katanya dari pada strukturnya termasuk situasi yang diciptakan tidak formal. Bahasa waria hanya dapat diperankan dalam komunikasi lisan dari pada tulisan dan digunakan oleh kalangan waria saja terutama di kota-kota besar. Dengan demikian, bahasa waria diperuntukkan untuk pergaulan sesama waria dalam kondisi dan situasi yang tidak resmi dan tidak perlu dipelajari secara formal di lingkungan masyarakat karena wujud penggunaannya masih sangat terbatas, bersifat obrolan dan nonilmiah. Dalam tinjauan pragmatik, kalimat bahasa waria lebih menekankan pada pembicaraan yang membahas mengenai sindiran kepada orang lain dan membahas mengenai laki-laki. Seperti kalimat "tarrangna...piro minjo neka lanangти...?" yang berarti banyak mungkin itu untuk bayar cowokmu..? Pada kalimat tersebut, orang-orang di luar kelompok waria tidak akan mengerti apa maksud dari kalimat itu. Tetapi, para waria sangat jelas mengetahui dan mengerti kalau maksud dibalik kalimat tersebut yaitu untuk membayar laki-laki sebagai imbalan karena telah mau melayani si waria.

\section{Simpulan}

Berdasarkan hasil penelitian, penggunaan bahasa waria di kalangan waria di wilayah Gowa dan Takalar, serta beberapa tempat di Makassar, merupakan varian bahasa. Bahasa waria hanya digunakan oleh kelompok waria saja maupun orang-orang yang bergaul dan akrab dengan waria. Ciri khas bahasa waria memiliki penyimpangan makna. Bahasa waria dapat dinyatakan sebagai hasil modifikasi atau turunan dari bahasa Indonesia maupun bahasa daerah.

Penggunaan kosakata bahasa waria masih terbatas dan diperkirakan akan berkembang dan terus bertambah pada masa yang akan datang sesuai dengan kebutuhan yang diinginkan oleh kaum waria dalam menyampaikan sesuatu. Jumlah penggunaan kosakata tersebut masih minim dan belum dapat mewakili sepenuhnya dalam mengungkapkan semua ide, gagasan, perasaan, dan sebagainya kepada orang lain.

Kalimat-kalimat dalam bahasa waria dinyatakan, bahwa kalimatkalimat yang digunakan dalam percakapan tidak terikat pada situasi resmi, melainkan dalam situasi santai atau rileks. Struktur kalimat bahasa waria tidak terikat atau berdasarkan pola sintaksis bahasa Indonesia seperti pada subjek, predikat, objek, dan keterangan.

\section{Daftar Rujukan}

Chaer, Abdul. 2007. Linguistik Umum. Jakarta: Rineka Cipta.

Charles, W. Morris. 1938. Logical Positivism, Pragmatism and Scientific Empiricism. Paris: Hermann Et Cie. 
Departemen Pendidikan Nasional. 2001. Kamus Besar Bahasa Indonesia. Jakarta: Balai Pustaka.

\author{
Levinson, $\begin{gathered}\text { S.C. } \\ \text { Cambridge: }\end{gathered}$
Cambridge \\ Levinson, $\begin{gathered}\text { S.C. } \\ \text { Cambridge: }\end{gathered}$
Cambridge \\ University Press.
}

Samsuri. 1987. Analisa Bahasa: Memahami Bahasa Secara Ilmiah.Jakarta: Erlangga. 